\title{
Komposisi Biaya Sumber Daya Material dan Tenaga Kerja Pada Proyek Konstruksi Bangunan Gedung Sederhana
}

\author{
Rifat Aditya Hawari ${ }^{1}$ Cut Zukhrina Oktaviani ${ }^{2}$ Nurisra $^{3}$ \\ ${ }^{1}$ Mahasiswa, Jurusan Teknik Sipil, Universitas Syiah Kuala, Banda Aceh 23111, Indonesia \\ ${ }^{2,3}$ Jurusan Teknik Sipil, Universitas Syiah Kuala, Banda Aceh 23111, Indonesia. \\ Email: rifataditya77@gmail.com
}

\begin{abstract}
Building construction projects have project resources that consist of various types such as labor resources, materials and costs needed to carry out construction projects. The problem in this research is what percentage of the project resources consist of labor and material resources in simple building construction projects in Aceh Province. The scope of the study where project implementation began in 2015 until 2019, uses secondary data in the form of RAB documents and AHSP documents. This study aims to identify the proportion of costs from project resources in the form of labor and materials. This research was conducted on a simple building project in Aceh Province. The results of the study have obtained 10 data of simple building construction projects in Aceh Province, in the simple building the percentage of material resources obtained is the proportion of $61.83 \%$ and $20.09 \%$ of labor resources.
\end{abstract}

Keyword: cost proportion, material, labor, building construction

\begin{abstract}
Abstrak
Proyek konstruksi bangunan gedung memiliki sumberdaya proyek yang terdiri dari berbagai jenis seperti sumberdaya tenaga kerja, material dan biaya yang dibutuhkan untuk pelaksanaan proyek konstruksi. Permasalahan pada penelitian ini adalah berapa persentase proporsi sumberdaya proyek yang terdiri dari sumberdaya tenaga kerja dan material pada proyek konstruksi bangunan gedung sederhana di Provinsi Aceh. Ruang lingkup penelitian dimana pelaksanaan proyek dimulai pada tahun 2015 sampai dengan 2019, menggunakan data sekunder berupa dokumen RAB dan dokumen AHSP. Penelitian ini bertujuan mengidentifikasi proporsi biaya dari sumber daya proyek berupa tenaga kerja dan material. Penelitian ini dilakukan pada proyek bangunan gedung sederhana di Provinsi Aceh. Hasil penelitian telah didapatkan 10 data proyek konstruksi gedung sederhana di Provinsi Aceh, pada gedung sederhana diperoleh hasil persentase proporsi sumber daya material $61,83 \%$ dan sumber daya tenaga kerja $20,09 \%$.
\end{abstract}

Kata Kunci: Proporsi Biaya, Material, Tenaga Kerja, Gedung

\section{Pendahuluan}

Proyek konstruksi ialah suatu kegiatan yang berhubungan dengan upaya untuk mencapai suatu tujuan pembangunan dengan biaya, waktu dan mutu. Pada kegiatan proyek konstruksi tersebut, terdapat suatu proses dimana sumber daya proyek dikelola menjadi suatu hasil kegiatan berupa bangunan. Proyek konstruksi bangunan gedung terdiri dari sumberdaya yang memiliki sumberdaya tenaga kerja, sumberdaya peralatan, sumberdaya material, biaya dan waktu yang digunakan untuk pelaksanaan proyek konstruksi, dimana dalam menggunakan sumber daya tersebut diperlukan pengelolaan yang baik sehingga dapat dimanfaat secara optimal.

Pokok masalah dari penelitian ini yaitu berapa nilai komposisi biaya proporsi alokasi sumberdaya tenaga kerja dan sumberdaya material pada proyek bangunan gedung sederhana di Provinsi Aceh. Pada penelitian ini bertujuan untuk menghitung persentase proporsi biaya sumber daya proyek berupa tenaga kerja dan material. Penelitian dilakukan pada proyek konstruksi bangunan gedung di Provinsi Aceh menggunakan data sekunder berupa dokumen kontrak yang berisi dokumen RAB dan dokumen AHSP. Memberikan gambaran berapa nilai komposisi biaya proporsi sumberdaya yang meliputi sumberdaya tenaga kerja dan sumberdaya material. Hal tersebut dapat digunakan pada saat pelaksanaan proyek konstruksi bangunan gedung. Batasan pada penelitian ini adalah proyek konstruksi bangunan gedung sederhana dengan jumlah 10 sampel proyek dan proyek yang ditinjau dilaksanakan pada tahun anggaran 2015 sampai dengan tahun 2019.

\section{Tinjauan Kepustakaan}

\subsection{Proyek Konstruksi}

Mangare[1] menjelaskan proyek merupakan suatu rangkaian kegiatan dan kejadian yang saling berkaitan untuk mencapai tujuan tertentu dan membuahkan hasil dalam suatu jangka tertentu dengan memanfaatkan sumber daya yang tersedia. Ervianto[2] menjelaskan proyek konstruksi merupakan suatu rangkaian kegiatan yang hanya satu kali dilaksanakan dan umumnya berjangka waktu pendek. Dalam rangkaian kegiatan tersebut, terdapat suatu proses yang mengolah sumber 
daya proyek menjadi suatu hasil kegiatan yang berupa bangunan.

\subsection{Proporsi}

Pada Kamus Besar Bahasa Indonesia (KBBI)[3] menjelaskan proporsi adalah alokasi, bagian dan perimbangan. Maka dari itu pengertian proporsi pada proyek konstruksi adalah untuk melihat alokasi sumberdaya tenaga kerja dan sumberdaya material pada proyek konstruksi bangunan gedung.

\subsection{Sumber Daya Proyek Konstruksi}

Muzayanah menjelaskan sumberdaya sangat dibutuhkan guna melakukan pekerjaan-pekerjaan yang berupa komponen dan unsur proyek. Hal ini dilakukan terkait dengan kearutan perhitungan komponen biaya, waktu dan kualitas. Bagaimana cara memanage (dalam hal ini efektifitas dan efisiensi) penggunaan sumberdaya ini akan memberikan dampak biaya dan jadwal pelaksanaan pekerjaan ini. Khusus untuk hal sumberdaya, proyek menginginkan agar sumberdaya tersedia dalam quality dan quantity yang cukup untuk waktunya, dilakukan secara optimal dan dimobilisasi seefisien mungkin setelah tidak diperlukan.

\subsubsection{Sumber daya tenaga kerja (labor)}

Soeharto[4] menyatakan pada pelaksanaan proyek, sumberdaya tenaga kerja yang berupa manusia yaitu factor penentu kejayaan pada sebuah proyek. Rincian dan intensitas kegiatan proyek berganti dengan cepat sepanjang siklusnya, sehingga penyediaan capacity tenaga kerja harus meliputi pekerjaan jenis dan kapan tenaga kerja diperlukan.

\subsubsection{Sumber daya material (material)}

Vlack[5] menjelaskan material yang dispesifikasi harus memiliki sifat yang sesuai pertama-pertama untuk produksi, dan selanjutnya untuk tujuan pemakaiannya. Produk tidak boleh gagal selama pemakaian, yang merupakan tanggung jawab produsen. Material merupakan suatu bahan yang diproduksi oleh pabrik dan dapat diperoleh dari pembelian dalam negeri, luar negeri dan pengolahan atau produksi yang dilakukan sendiri. Dan di dalam proyek konstruksi material merupakan bagian komponen yang sangat penting.

\subsubsection{Sumber daya biaya (cost)}

Muzayanah[6] menjelaskan biaya merupakan modal awal dari pengadaan suatu konstruksi. Dimana biaya dapat didefinisikan sebagai jumlah segala usaha dan pengeluaran yang dilakukan dalam mengembangkan, memproduksi, dan mengaplikasikan produk. Penghasil produk selalu memikirkan akibat dari adanya biaya terhadap kualitas, reliabilitas, dan maintainability karena ini akan berpengaruh terhadap biaya bagi pemakai produk. Biaya produksi sangat perlu diperhatikan karena sering mengandung sejumlah biaya yang tidak perlu untuk digunakan pada suatu produk ataupun pada suatu proyek konstruksi dan biaya pun akan menjadi sia-sia.

\subsubsection{Sumber daya waktu (time)}

Muzayanah menjelaskan waktu ialah sumberdaya pokok pada pelaksanaan sebuah proyek. Pengendalian dan perencanaan waktu dilakukan dengan mengatur scheadule, dengan cara mengidentifikasi titik kapan pekerjaan dimulai dan kapan berhenti. Perencanaan dan pengendalian ialah bagian dari penyusunan biaya. Pada hubungan ini, sering kali pengelola proyek beranggapan bahwa penyelesaian proyek semakin cepat semakin baik.

\subsubsection{Sumber daya peralatan (equiptmentl)}

Di dalam suatu proyek yang akan dilaksanakan, penyedia jasa konstruksi menentukan peralatan yang akan digunakan di proyek tersebut. Equipment yang digunakan haruslah cocok sehingga proyek bisa berjalan dengan tanpa hambatan. Pengadaan equipment dilakukan pada tahap perencanaan, dimana jumlah, jenis, dan capacity peralatan merupakan faktor-faktor penentu. Sobirin[7] menjelaskan peralatan konstruksi yang diinginkan merupakan peralatan yang dibutuhkan untuk melakukan pekerjaan konstruksi secara mekanis. Ini dapat berupa crane, grader, scraper, truck, pengeruk tanah (back hoe), kompresor udara, dan lainnya.

\subsection{Analisa Harga Satuan Pekerjaan (AHSP)}

Permen PU nomor 11 tahun 2013[8] menjelaskan bahwa Analisis Harga Satuan Pekerjaan yang kemudian disingkat dengan AHSP ialah perhitungan kebutuhan biaya tenaga kerja, bahan dan peralatan untuk menemukan harga satuan atau satu jenis pekerjaan tertentu. Analisa harga satuan pekerjaan merupakan suatu cara menghitung harga satuan pekerjaan konstruksi yang dijabarkan di dalam perkalian kebutuhan alat, bahan bangunan, dan upah kerja dengan harga bahan bangunan, standar pengupahan pekerja dan harga sewa atau beli peralatan untuk menyelesaikan per satuan pekerjaan konstruksi. gambar harga satuan pekerjaan, yang dipengaruhi oleh faktor material, upah tenaga kerja dan peralatan dapat dilihat pada gambar 1

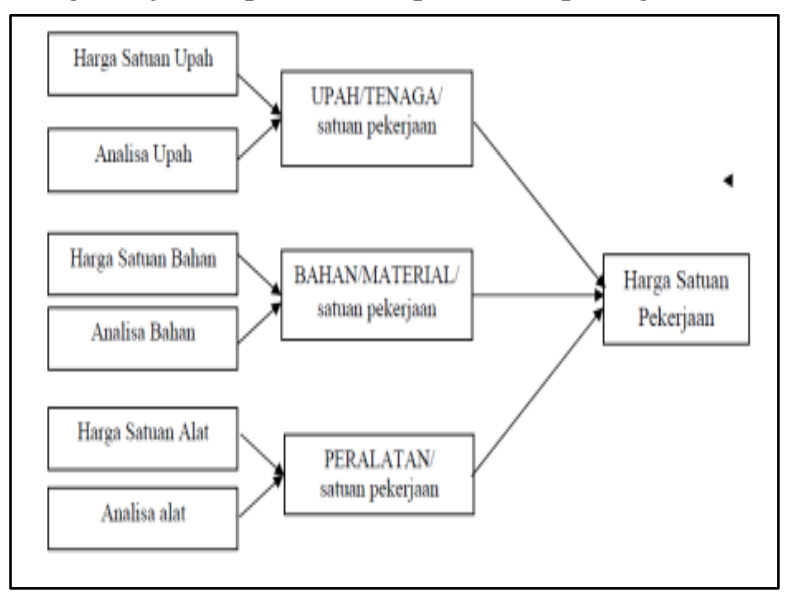

Gambar 1 Bagan Analisa Harga Satuan Pekerjaan

\subsection{Teknik Pengumpulan Data}

Yusuf[9] menjelaskan metode pengumpulan data adalah tahapan yang sangat strategis dalam penelitian, karena tujuan utama dari penelitian yaitu untuk 
mendapatkan data. dokumentasi menjelaskan bahwa dokumen dalam arti luas adalah setiap proses pembuktian yang didasari atas jenis sumber apapun, baik itu yang bersiftat tertulis, lisan, gambaran, atau arkeologis. Teknik dokumentasi adalah salah satu metode pengumpulan data yang digunakan dalam penelitian sosial untuk menelusuri data historis.

\subsection{Jenis Data}

Jenis data dalam penelitian ini ialah data sekunder, data sekunder adalah data yang diperoleh dari institusi atau lembaga tertentu. Dapat diperoleh melalui bahan tambahan yang berasal dari sumber tertulis seperti majalah ilmiah dan buku, sumber data arsip, dokumen resmi dan dokumen pribadi. Data sekunder juga bisa didapatkan melalui foto. Foto menghasilkan data deskriptif yang cukup berharga dan dapat digunakan untuk menelaah data yang dilihat dari segi subjektif.

\section{Metode Penelitian}

\subsection{Alur Penelitian}

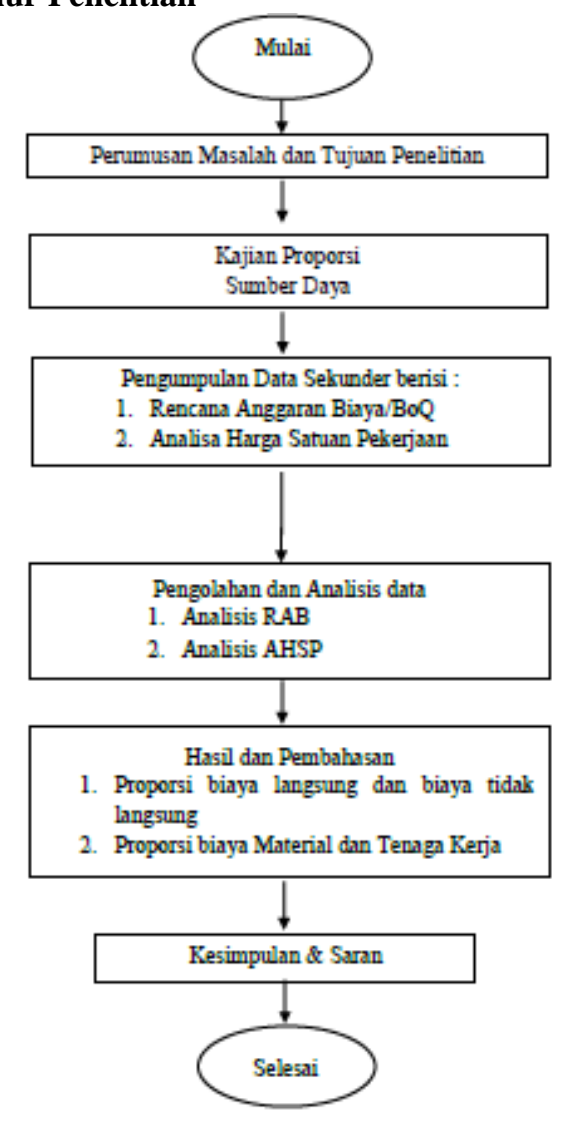

Gambar 2 Bagan Alir

\subsection{Obyek Penelitian}

Obyek dalam penelitian ini dilakukan pada proyek konstruksi bangunan gedung sederhana. Proyek dimulai pada tahun anggaran 2015 sampai dengan tahun 2019 di Provinsi Aceh.

\subsection{Jenis dan Sumber Data}

Jenis data di dalam penelitian ini adalah data dokumen kontrak proyek konstruksi yang berisi dokumen Rencana Anggaran Biaya atau RAB dan dokumen Analisa Harga Satuan Pekerjaan atau AHSP pada proyek konstruksi bangunan gedung sederhana di Provinsi Aceh, dari tahun anggaran 2015 sampai dengan tahun 2019. Sumber data dari penelitian ini menggunakan data sekunder yang diperoleh dari Dinas Perumahan Rakyat dan Kawasan Permukiman Provinsi Aceh, Konsultan dan Kontraktor.

\subsection{Teknik Pengumpulan Data}

Pengumpulan data yang digunakan pada penelitian ini yaitu teknik dokumentasi. Teknik dokumentasi adalah salah satu cara pengumpulan data kuantitatif dengan menganalisa atau melihat dokumen-dokumen yang dibuat oleh subjek sendiri atau oleh orang lain tentang subjek. Pengumpulan data yang digunakan ialah pengumpulan data dokumen kontrak yang berisi dokumen RAB atau Rencana Anggaran Biaya pada pembangunan gedung di Provinsi Aceh dan dokumen Analisa Harga Satuan Pekerjaan atau AHSP. RAB diperoleh dari Dinas Perumahan Rakyat dan Kawasan Permukiman Provinsi Aceh, Kontraktor dan Konsultan.

\subsection{Teknik Analisis}

Teknik yang digunakan pada penelitian ini yaitu analisa deskriptif. Analisis deksriptif digunakan untuk menganalisis data yang terkumpul sebagaimana semestinya tanpa bermaksud membuat sebuah kesimpulan yang berlaku untuk umum, karena analisis ini menggambarkan persentase alokasi sumber daya pada proyek konstruksi bangunan gedung. Teknik analisis ini dipakai untuk melihat hasil dari analisis data kontrak atau RAB dan hasil analisis harga satuan pekerjaan (AHSP).

\subsubsection{Analisis Dokumen Rencana Anggaran Biaya}

Analisis RAB dilakukan dengan cara mempelajari dan menjabarkan item-item yang berkaitan dengan komponen sumber daya proyek yang ada di dalam RAB dan kemudian dilakukan perkalian dengan koefisien yang ada di dalam analisa harga satuan pekerjaan. Selanjutnya dilakukan rekapitulasi atau pengumpulan data RAB yang diperoleh ini tidak dimunculkan nama proyek dan nama instansi perusahaan.

\subsubsection{Analisis Dokumen Analisa Harga Satuan Pekerjaan}

Analisis harga satuan pekerjaan dilakukan dengan mempelajari dan menjabarkan komponenkomponen sumberdaya material dan sumberdaya tenaga kerja. Dokumen Analisa Harga Satuan Pekerjaan atau AHSP terdapat analisa-analisa yang memuat koefisien dan harga untuk sumberdaya material dan sumberdaya tenaga kerja. Harga pada item sumberdaya proyek tersebut kemudian dilakukan perhitungan untuk semua jenis pekerjaan yang terdapat pada suatu proyek konstruksi. Hasil perhitungan semua item pekerjaan pada pekerjaan konstruksi bangunan gedung kemudian 
didapatkan, maka dilakukan perhitungan alokasi biaya sumber daya proyek dan juga untuk mendapatkan berapa nilai persentase proporsi sumberdaya material dan tenaga kerja pada proyek konstruksi bangunan gedung sederhana.

Analisa harga satuan pekerjaan yang dipakai untuk penelitian ini menggunakan Standar Nasional Indonesia AHSP untuk bangunan gedung tahun 2013. Hasil analisis dokumen Analisa Harga Satuan Perkerjaan (AHSP) dibuat dalam tabel perhitungan alokasi biaya sumber daya untuk setiap proyek konstruksi bangunan gedung sederhana. Analisis proporsi untuk komposisi biaya sumberdaya proyek dilakukan setelah dihitung biaya setiap komponen yang terdapat pada sumberdaya material dan sumberdaya tenaga kerja. Nilai proporsi yang telah didapatkan hasilnya bervariasi pada sumberdaya tenaga kerja dan sumberdaya material.

\section{Hasil dan Pembahasan}

Pada bab ini membahas dari hasil penelitian dan pembahasan yang terdapat pada penelitian ini berupa dokumen RAB dan AHSP gedung sederhana

\subsection{Hasil Pengumpulan Data}

Data yang telah dikumpulkan didapatkan dari Dinas Perumahan Rakyat dan Kawasan Permukiman Provinsi Aceh, konsultan dan kontraktor. Data yang terkumpul sebanyak 10 sampel proyek konstruksi, berupa 10 sampel proyek gedung sederhana. Rekapitulasi data kontrak proyek gedung sederhana dapat dilihat pada Tabel 1.

Tabel 1 Rekapitulasi Data Kontrak Proyek

\begin{tabular}{cccc} 
Kode & Tahun & $\begin{array}{c}\text { Nilai Kontrak } \\
(\mathrm{Rp})\end{array}$ & Lokasi \\
\hline A & 2017 & Rp.192.000.000 & Pidie \\
\hline B & 2016 & Rp.185.000.000 & Pidie \\
\hline C & 2015 & Rp.192.000.000 & Pidie \\
\hline D & 2017 & Rp.685.125.000 & Banda Aceh \\
\hline E & 2016 & Rp.423.662.000 & Banda Aceh \\
\hline F & 2016 & Rp.172.800.000 & Banda Aceh \\
\hline G & 2017 & Rp.72.000.000 & Aceh Utara \\
\hline H & 2017 & Rp.96.000.000 & Banda Aceh \\
\hline I & 2017 & Rp.96.000.000 & Aceh Besar \\
\hline J & 2017 & Rp.144.000.000 & Banda Aceh \\
\hline
\end{tabular}

\subsubsection{Gambaran Umum Objek Penelitian}

Pada analisis data terdapat beberapa proyek yang di evaluasi yaitu proyek bangunan gedung sederhana yang berasal dari Dinas Perumahan Rakyat dan Kawasan Permukiman Provinsi Aceh, Kontraktor, dan Konsultan. Data yang dikumpulkan sebanyak 10 proyek gedung sederhana. Nilai kontrak proyek gedung sederhana paling rendah dimulai dengan Rp.72.000.000,00 dan nilai kontrak proyek gedung sederhana paling tinggi dimulai dengan Rp.685.125.000,00. Lokasi pada objek penelitian gedung sederhana tersebar di Provinsi Aceh dan tepatnya berada di Kabupaten Pidie, Kabupaten Aceh Besar, Kabupaten Aceh Utara dan Kota Banda Aceh.

\subsubsection{Kelompok Data}

\subsubsection{Kelompok Data Lokasi Proyek}

Lokasi pada penelitian ini tersebar di Provinsi Aceh terdapat pada 3 Kabupaten dan 1 Kota di Provinsi Aceh dengan rincian persebaran meliputi Kabupaten Pidie (3 Proyek), Kabupaten Aceh Utara (1 Proyek), Kabupaten Aceh Besar (1 Proyek) dan Kota Banda Aceh (5 Proyek). Distribusi data berdasarkan lokasi proyek dapat dilihat pada Gambar 3.

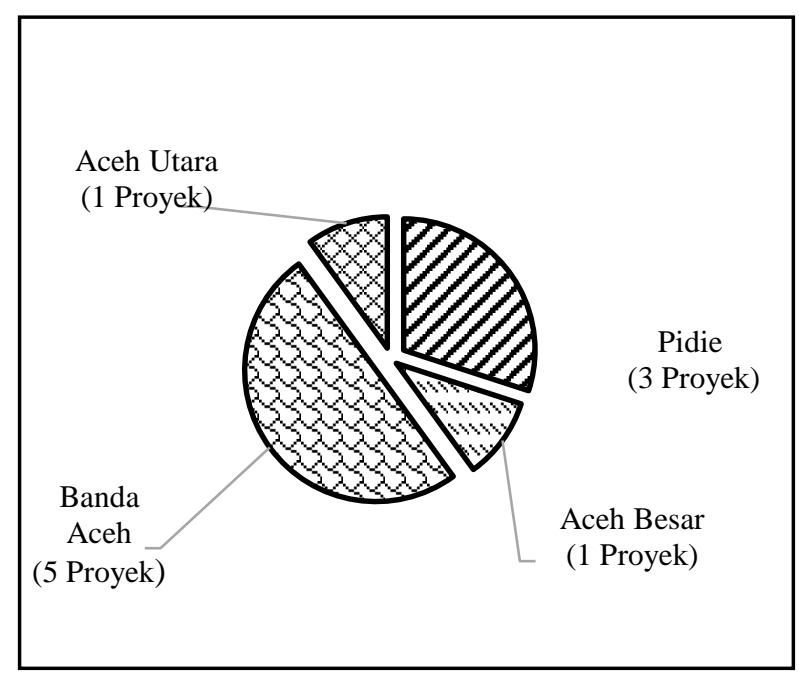

Gambar 3 Kelompok Data Lokasi Proyek

\subsubsection{Kelompok Data Tahun Anggaran}

Lokasi pada penelitian ini ditinjau yaitu proyek pada tahun anggaran pelaksanaan yang dikumpulkan pada penelitian ini yaitu 5 tahun anggaran yaitu tahun 2015 sampai dengan tahun 2019 dengan rincian persebaran yaitu tahun anggaran 2015 (1 proyek), tahun 2016 (3 proyek), tahun 2017 (6 proyek) dan tahun 2018

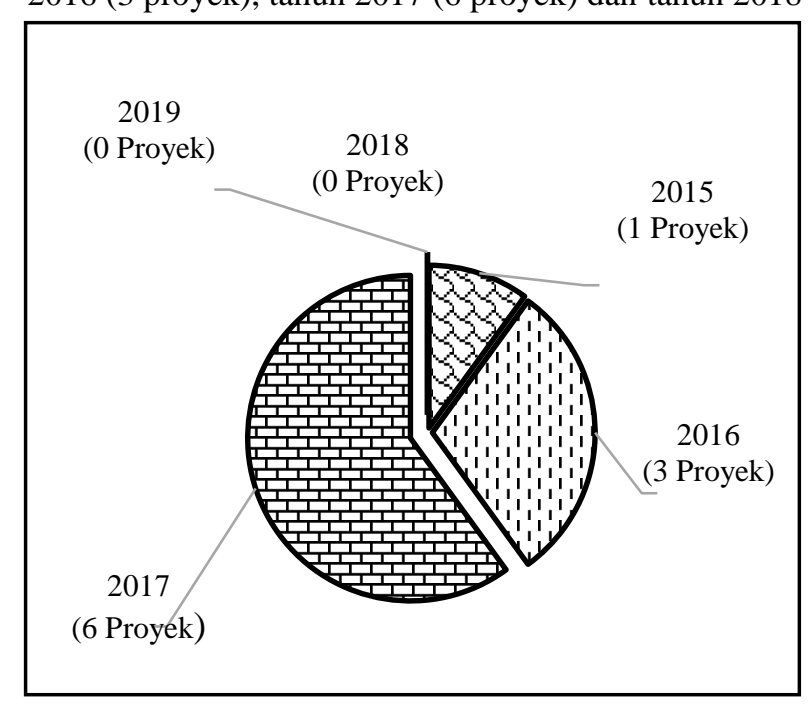


(0 proyek) dan 2019 (0 proyek). Distribusi data berdasarkan tahun anggaran dapat dilihat pada Gambar 4.

\section{Gambar 4 Kelompok Data Tahun Anggaran}

4.2 Hasil Penelitian

4.2.1 Persentase Komposisi Biaya Sumber Daya Proyek Gedung Sederhana

Analisis proporsi dilakukan setelah dihitung biaya setiap komponen yang ada pada sumberdaya tenaga kerja dan sumberdaya material. Proporsi biaya pada setiap sumberdaya kemudian dilakukan pengolahan sehingga diperoleh nilai komposisi biaya dan nilai persentase proporsi 10 sampel proyek gedung sederhana. Hasil analisis proporsi biaya sumberdaya proyek telah didapatkan nilai komposisi biaya dan persentase proporsi biaya yang bervariasi pada gedung sederhana kemudian dilakukan rata-rata nilai persentase komposisi biaya dan dapat dilihat pada Tabel 2.

Tabel 2 Perhitungan rata-rata Persentase Komposisi Biaya Sumber Daya Proyek Gedung Sederhana

\begin{tabular}{|c|c|c|c|c|c|c|}
\hline \multirow[t]{2}{*}{$\mathrm{N}_{0}$} & \multirow[t]{2}{*}{ Kode } & \multirow[t]{2}{*}{ Tahun } & \multicolumn{2}{|c|}{ Nilai Kontrak Proyek (Rp) } & \multicolumn{2}{|c|}{$\begin{array}{c}\text { Sumber Daya Proveke } \\
(\%)\end{array}$} \\
\hline & & & & & $\begin{array}{l}\text { Tenaga } \\
\text { Kerja }\end{array}$ & Material \\
\hline 1 & A & 2017 & $\mathrm{Rp}$ & $192,000,000.00$ & 27.95 & 52.5 \\
\hline 2 & B & 2016 & $\mathrm{Rp}$ & $185,000,000.00$ & 18.94 & 62.41 \\
\hline 3 & $\mathrm{C}$ & 2015 & $\mathrm{Rp}$ & $192,000,000.00$ & 24.74 & 49.96 \\
\hline 4 & D & 2017 & $\mathrm{Rp}$ & $685,125,000.00$ & 18.6 & 79.4 \\
\hline 5 & E & 2016 & $\mathrm{Rp}$ & $423,662,000.00$ & 18.67 & 62.75 \\
\hline 6 & F & 2016 & $\mathrm{Rp}$ & $172,800,000.00$ & 41.71 & 39.01 \\
\hline 7 & G & 2017 & Rp & $72,000,000.00$ & 10.21 & 66.3 \\
\hline 8 & $\mathrm{H}$ & 2017 & Rp & $96,000,000,00$ & 8.8 & 72.96 \\
\hline 9 & I & 2017 & Rp & $96,000,000.00$ & 17.21 & 65.44 \\
\hline 10 & J & 2017 & Rp & $144,000,000.00$ & 14.03 & 67.59 \\
\hline & & & & & 20.09 & 61.83 \\
\hline
\end{tabular}

Berdasarkan hasil penelitian maka dapat diperoleh beberapa informasi sebagai berikut :

1. Sumber daya tenaga kerja beragam dari $8,80 \%$ sampai dengan 41,71\%, kemudian dirata-ratakan sehingga didapatkan persentase rata-rata sumber daya tenaga kerja sebesar 20,09\%.

2. Sumber daya material bervariasi dari $39,01 \%$ sampai dengan $72,96 \%$, kemudian dirata-ratakan sehingga didapatkan persentase rata-rata sumber daya material sebesar $61,83 \%$.

\subsubsection{Klasifikasi Biaya Proyek}

Analisa pada klasifikasi biaya ini ini dilakukan dengan cara melakukan penjumlahan kebutuhan biaya langsung yaitu sumber daya dan biaya tidak langsung yaitu non sumber daya. Biaya Langsung merupakan total biaya yang berhubungan langsung dengan fisik proyek. Biaya langsung meliputi biaya sumberdaya tenaga kerja dan sumberdaya material.

Biaya tidak langsung ialah keseluruhan biaya yang terhubung secara tidak langsung, yang dibebankan kepada proyek. Biaya tidak langsung yaitu non sumber daya yang mencakup biaya pajak (tax), biaya keuntungan (profit), biaya risiko (overhead) dan biaya lainnya. Hasil analisis data klasifikasi biaya dapat dilihat pada Tabel 3

Tabel 3 Klasifikasi Proyek Gedung Sederhana

\begin{tabular}{|c|c|c|c|c|c|c|}
\hline \multirow[t]{2}{*}{ No } & \multirow{2}{*}{\multicolumn{2}{|c|}{ Kode Tahun }} & \multicolumn{2}{|c|}{ Nillai Kontrak Provejek (Rp) } & \multicolumn{2}{|c|}{ Klasifikasi Biaya } \\
\hline & & & & & $\begin{array}{l}\text { Biaya } \\
\text { Langolng }\end{array}$ & $\begin{array}{l}\text { Biaya Tidak } \\
\text { Lanngsung }\end{array}$ \\
\hline 1 & A & 2017 & $\mathrm{Rp}$ & $192,000,000,00$ & 80.45 & 11.7 \\
\hline 2 & B & 2016 & $\mathrm{Rp}$ & $185,000,000.00$ & 81.35 & 18.65 \\
\hline 3 & $C$ & 2015 & $\mathrm{Rp}$ & $192,000,000,00$ & 74.69 & 25,31 \\
\hline 4 & D & 2017 & $\mathrm{Rp}$ & $685,125,000.00$ & 98 & 2 \\
\hline 5 & E & 2016 & Rp & $423,662,000.00$ & 81.42 & 18.58 \\
\hline 6 & $\mathrm{~F}$ & 2016 & $\mathrm{Rp}$ & $172,800,000.00$ & 80.72 & 19.28 \\
\hline 7 & G & 2017 & $\mathrm{Rp}$ & $72,000,000,00$ & 76.5 & 23.5 \\
\hline 8 & $\mathrm{H}$ & 2017 & Rp & $96,000,000.00$ & 81.76 & 18.24 \\
\hline 9 & I & 2017 & $\mathrm{Rp}$ & $96,000,000.00$ & 82.65 & 17.35 \\
\hline 10 & J & 2017 & Rp & $144,000,000,00$ & 81.63 & 18.37 \\
\hline & & & ataratata $(\%)$ & & 81.92 & 17.3 \\
\hline
\end{tabular}

Berdasarkan hasil penelitian maka diperoleh beberapa informasi sebagai berikut :

1. Biaya langsung beragam dari $74,69 \%$ sampai dengan $98 \%$, kemudian dirata-ratakan sehingga didapatkan persentase rata-rata biaya langsung sebesar $81,92 \%$.

2. Biaya tidak langsung beragam dari $2 \%$ sampai denan $25,31 \%$, kemudian dirata-ratakan sehingga didapatkan persentase rata-rata biaya tidak langsung sebesar $17,30 \%$.

\subsubsection{Alokasi Biaya Sumber Daya Proyek}

Analisis alokasi biaya pada sumberdaya proyek dilakukan dengan cara menghitung biaya setiap komponen yang ada pada setiap sumberdaya tenaga kerja dan sumberdaya material. Alokasi biaya disetiap sumber daya setelah itu dilakukan pengolahan sehingga diperoleh persentase nilai komposisi 10 sampel proyek gedung sederhana. Nilai alokasi biaya yang sudah diperoleh mendapatkan hasil yang beragam pada sumberdaya tenaga kerja dan sumberdaya material. 


\subsection{Pembahasan}

Proyek konstruksi gedung yang ditinjau yaitu gedung sederhana. Pembiayaan pada proyek konstruksi gedung sederhana terdapat biaya langsung dan biaya tidak langsung, biaya langsung meliputi sumberdaya tenaga kerja dan sumberdaya material, sedangkan biaya tidak langsung meliputi pajak pertambahan nilai (ppn), biaya risiko (overhead) dan biaya keuntungan (profit).

Pada data proyek konstruksi gedung sederhana dari 9 sampel komponen paling besar pada biaya langsung adalah lebih dominan biaya sumber daya material sedangkan pada 1 sampel dengan kode proyek F komponen paling besar pada biaya langsung adalah sumber daya tenaga kerja. Biaya tidak langsung komponen paling besar adalah biaya pajak pertambahan nilai (ppn) dari 9 sampel data, namun terdapat 1 sampel dengan kode proyek D tidak terdapat biaya pajak, biaya risiko (overhead) dan biaya keuntungan (profit). Pada proyek dengan kode D merupakan sistem swakelola sehingga tidak terdapat biaya pajak pertambahan nilai (ppn), biaya risiko (overhead) dan biaya keuntungan (profit). Biaya langsung proyek konstruksi gedung sederhana didapatkan beragam nilai dimulai dari $74,69 \%$ sampai dengan $98 \%$ kemudan dirata-ratakan menjadi $81,92 \%$. Biaya tidak langsung atau non sumber daya didapatkan beragam nilai dimulai dari $2 \%$ sampai dengan $25,31 \%$ kemudian dirata-ratakan menjadi $17,30 \%$.

Hasil penelitian biaya langsung atau sumber daya telah diperoleh nilai persentase komposisi biaya sumber daya material pada proyek konstruksi bangunan gedung sederhana menempati persentase paling tinggi dengan nilai komposisi biayanya berkisar antara $39,01 \%$ sampai dengan $72,96 \%$ dan diperoleh nilai rata-rata komposisi biaya sumber daya material sebesar $61,83 \%$ dari total biaya proyek. Nilai komposisi biaya sumber daya tenaga kerja menempati persentase paling rendah dengan nilai proporsi berkisar antara $8,80 \%$ sampai dengan $41,71 \%$ dan diperoleh nilai rata-rata komposisi biaya sumber daya tenaga kerja sebesar 20,09\% dari total biaya proyek. Adapun grafik persentase komposisi biaya pada proyek gedung sederhana dapat dilihat pada Gambar 3

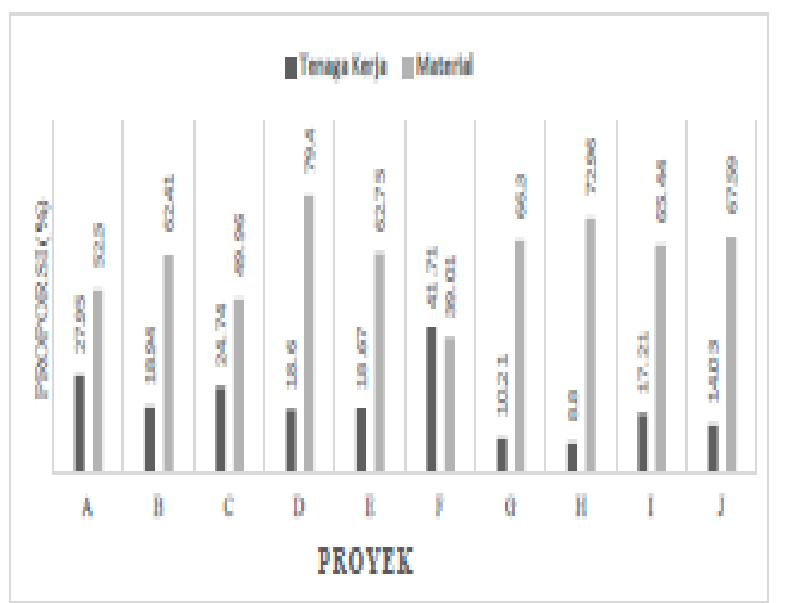

Gambar 3 Persentase Komposisi Biaya Proyek Gedung Sederhana

\section{Kesimpulan dan Saran}

\subsection{Kesimpulan}

Kesimpulan yang diambil dan diperoleh dari hasil penelitian mengenai komposisi biaya sumber daya proyek konstruksi bangunan gedung sederhana :

1. Hasil analisa data komposisi sumber daya proyek gedung sederhana didapatkan nilai rata-rata paling tinggi yaitu pada sumber daya material dengan nilai sebesar $61,83 \%$.

2. Hasil nilai rata-rata paling kecil pada proyek konstruksi bangunan gedung sederhana yaitu sumberdaya tenaga kerja dengan nilai sebesar $20,09 \%$.

3. Pada proyek konstruksi tidak hanya terdapat biaya sumber daya atau langsung tetapi juga termasuk biaya non sumber daya atau biaya tidak langsung.

4. Persentase untuk nilai biaya langsung pada gedung sederhana sebesar $81,92 \%$ dan biaya tidak langsung pada gedung sederhana sebesar 17,30\%.

\subsection{Saran}

Berikut adalah beberapa saran yang bisa menjadi pertimbangan untuk studi kasus selanjutnya yaitu sebagai berikut :

1. Lokasi proyek yang berbeda memiliki nilai harga satuan pekerjaan yang berbeda, sehingga nilai proporsi sumber daya proyek di setiap daerah akan berbeda.

2. Jenis proyek pada penelitian ini hanya pada proyek konstruksi bangunan gedung sederhana, sehingga diperlukan penelitian lain pada jenis proyek konstruksi lainnya seperti proyek konstruksi bangunan gedung non sederhana, konstruksi bendungan, konstruksi jembatan maupun proyek konstruksi lainnya.

3. Jumlah sampel proyek pada penelitian selanjutnya perlu ditambahkan lebih banyak lagi, sehingga hasil yang diperoleh dapat terwakili dari banyaknya proyek pada daerah yang ditinjau.

4. Pada penelitian ini dapat digunakan oleh pelaksana pada saat pelaksanaan bangunan gedung sederhana

\section{Daftar Kepustakaan}

[1] Mangare, dan B. F. Sompie, Kajian Proporsional Model Sumber Daya Pada Proyek Konstruksi Gedung, Manado, Jurnal Ilmiah Media Engineering 2(3) : 163-171, 2012.

[2] W. I. Ervianto, Manajemen Proyek Konstruksi, ANDI Yogyakarta, Yogyakarta, 2005. 
[3] Kamus Besar Bahasa Indonesia (Online), tersedia di (https://kbbi.kemendikbud.go.id/entri/proporsi, diakses 30 Juli 2019).

[4] I. Soeharto, Manajemen Proyek Dari Konseptual Sampai Operasional, Erlangga, Jakarta, 1997.

[5] L. H. Van Vlack, Elemen-elemen Ilmu dan Rekayasa Material, Erlangga, Jakarta, 2001.

[6] Y. Muzayanah, Pemodelan Proporsi Sumber Daya Proyek Konstruksi, Thesis, Magister Teknik Sipil Universitas Diponegoro, Semarang, 2008.

[7] M. Sobirin, Kinerja Proyek Konstruksi Bangunan Gedung Di Pengaruhi Oleh Beberapa Faktor Seperti Sumber Daya Manusia, Sumber Daya Alat Dan Sumber Daya Material, Jakarta Selatan, Jurnal Sains dan Teknologi 2(2) : 117-132, 2016.

[8] Anonim, Peraturan Pemerintah Republik Indonesia Nomor 295 Tahun 1997, Tentang Pedoman Teknis Pembangunan Bangunan Gedung Negara, Ditjen Ciptakarya, Departemen Pekerjaan Umum..

[9] A. M. Yusuf, Metode Penelitian: Kuantitatif, Kualitatif dan Penelitian Gabungan, Kencana, Jakarta, 2017. 